to be a strong one, as a weak one will answer the purpose equally well, and be much less liable to cause irritation. Perhaps a solution of the biniodide of mercury of the strength of 1 in 1,000 is the best that can be employed. This being done, then the whole foot is to be encased in dressing consisting of double cyanide of mercury and zinc gauze moistened by being wrung out with the above solution. It is necessary that this dressing should be very securely fixed, for, if it were to shift, the skin surface already prepared would again become fouled. The dressing is left in place till the Tuesday morning, when it is removed, and the whole process as just described is repeated in every detail so far as the foot is concerned. It may be questioned as to what is the necessity for this double preparation.

It is true that while the first cleansing had the effect of rendering the surface of the skin probably nearly aseptic, yet it did not touch the depths of the integument in which lie hidden the glands with their teeming stores of bacteria. It is also a fact that these glands will continue to secrete and bring their products to the surface, together with the micro-organisms inclosed in them. The second cleansing recommended is to remove these bacteria, which have by this time arrived at the summit of the gland tubes. The dressing which has been applied after this second preparation is to be left in place until it is removed on the operation table. On the Wednesday morning, after the patient has been anæsthetised, the dressing is to be taken off the part, and the whole foot again subjected to the vigorous cleansing that it has received on the two previons occasions. From repeated trial of this method of attempting to obtain asepsis it has been found to be very $t$ fficient, and at the same time one which is not very difficult in its execution, and that even in a private house.

In a future paper the preparation of the surgeon's hands, those of his assistants, and the cleansing of the instruments will be considered, as well as the procedure to be adopted in emergency cases.

\section{NOTIFICATION AND ISOLATION.}

In opening the section of State Medicine at Edinburgh the president, Professor Sir Henry Littlejohn, said that one of the most melancholy things he had to mention was that there had been no great discovery in medicine or surgery but had been violently opposed by their own profession. The professicn, to a man, in Edinburgh opposed the introdaction of the Notification Act. The two Royal Colleges of Surgeons and Physicians instructed Parliamentary counsel to oppose the introduction of any such clause in the Bll which was being promoted by the Corporation of Edinburgh. Luckily, a kind Providence enabled them to catch their opponents napping. Something occurred; he did not know what, but their "omnibus" Bill was quietly shoved through Parliament, and the fatal clause was contained in it, and he had the satisfaction of intimating to his colleagues that this Act had been passed, and that it was his duty to carry it out in the most comfortable manner possible, and with the least offence to anjone. It had been a great success. They had a diminished mortality from all infectious disease. Edinburgh had the reputation in one or two volumes to be found in their library of being a fever city. They had had outbreaks. Iet them think of 6,000 cases of typhoid in the course of a year! Medical s shcols suffered, f.r medical stadents died. That frightened parents, and Edinburgh got a bad reputation. Medical men in charge of the typhus also fell. They hat an enormous mortality, both in the new and the old town. Rich and poor suffered alike, for in no part of the town had they any one quarter like a Ghetto. In the old town they had the University and their Law Courts, and if there was an epidemic in the old town, owing to the free communication between the southern part of the town and the new town, epidemics spread. That disease had been actually wiped out, chiefly owing to the improvements made in the rookeries and dens of the poor, and also specially by the Notification Act. In these upright "streets," accommodating 200 people, typhus spread like wildfire. Typhus epidemics, however, were a thing of the past, and no longer would Edinburgh be called a fever city so far as that scourge was concerned. They had sporadic cases, but they pounced upon them, and stamped out the disease. The strange thing in this connection was that they found the disease, typhus, to be as fatal as ever. He remembered Sir James Simpson, that man of genius, saying to him that diseases were undergoing cycles of changes, and were becoming less and less, that typhus would work itself out, and so on; but so far as their experience in Edinburgh was con. cerned typhus was as virulent as ever, and if it were not for their pouncing down upon it through the Notification Act, he believed Edinburgh would again acquire an unenviable notoriety. R pital, Sir Henry said they had located in the centre of the poorest part of Edinburgh the hospital for infectious diseases, and that morning it contained over 300 cases; but, so far from that circumstance causing the disease to spread, it was remarkable that the immediate neighbourhood of the hospital showed a less amount of infectious disease than other parts of the city. He dissented from the view that there could be aërial communication of small-pox to any distance, and said he was perfectly sure that with the most ordinary care the disease would not spread.

\section{A CASE OF INTUSSUSCEPTION.}

Reduction after Three Weeks' Duration.

So much depends on a due understanding of the length of time during which an intussusception may continue without the formation of such adhesion as to render its reduction impossible, that great interest attaches to a report by Dr. Penrose and Mr. Kellock of a case of intussusception of the cæsum which was reduced with comparative ease after it had existed for three weeks. The case was that of a male child aged sixteen months, who was admitted into the Hospital for Sick Children, Great Ormond Street, on account of pain in the abdomen. Three weeks before admission the mother noticed that the child had pain in the abdomen which came on suddenly, causing him to roll about and double himself up. These attacks had occurred at least once a day, and had been accompanied on three occasions by vomiting. There was no blood in the strols and no straining. The child was strikingly apathetic. In the left iliac fossa a sausage-shaped tumour was felt, lying in the direction of the descending colon and reaching to just below the anterior superior spine of the ilium. It was very hard and somewhat irregular in outline. A less defined tumour could be 
traced as a continuation of this to the left hypochondrium, across the epigastrium, and down to the middle of the right lumbar region. The right iliac fossa appeared to be more empty than usual. On operation the intussusception was found to be one of the cæcum into itsele, the invaginated part reaching the descending colon. Reduction was effected with some difficulty, not, however, from adhesion, but from the thickness and hardness of the gut. No doubt the comparative facility with which reduction was effected was due in large measure to the seat of the mischief, namely, an intussusception of the cæcum into itself. There was thus comparatively little interference with the circulat:on in the invaginated portions of bowel, as shown by the absence of blood from the stool, and the nonformation of adhesions in the peritoneum. It must be remembered, however, that this is a somewhat rare variety of intussusception, and that the locality of the tumour cannot be always relied on to determine the particular variety of the condition which ma.y be present in a given case.

\section{UR AMIA.}

An admirable clinical lecture on uræmia, lately delivered by Sir Thomas Grainger Stewart, and published in the Practitioner, puts the main facts concerning that condition in a very clear light, at least so far as they appeal to the physician in his daily clinical work. We must first know what we mean by uræmia. The term is used in two senses. It is, on the one hand, regarded as being that condition of the nervous system which is apt to arise in the course of Bright's disease or other serious disease of the kidney; but a more accurate and satisfactory conception of uræmia is that which, in addition to the changes in the nervous system, recognises changes elsewhere, and especially in the alimentary system. Going back to causes, however, it is to be regarded as a result of a poisoning of the system in consequence of damage of the kidney. The symptoms, then, of uræmia have to do with the nervous system and the digestive system, and, both in regard to treatment and prognosis, especially to prognosis, it is important to bear in mind the distinction between the acute and the chronic forms of the disease, the former being often carable, the latter hardly $\in$ ver. So far as the nervous system is concerned, in some cases sensory changes may be the most marked; in others, motor changes; in others, again, cerebral or mental disturbances; and cases also oc jur in which the organic reflexes are interfered with, as, for example, the process of resp ration. Take an ordinary convalsive attack of um mia. A patient is taken with general convulsions, with more or less profound unconsciousness. This may occur in the case of a child suffering from dropsy after scarlet fever, but it may also occur in the case of a man who, although rather out of health, perhaps, has been going about with nothing de. finite enough the matter with him to take him to a doctor, when he is sudcenly seized with what seems to be an attack of epilepsy, after which he may be found to remain unconscious. The high tension, or renal pulse, however, soon tells us what is the origin of the attack. In both these cases the onset of the convulsion is sudden. But in the chronic form the signs of uræmic poisoning come on gradually. A man becomes somewhat torpid. "He begins to be indifferent in his manner and slow in his replies, and somewhat dragging in speech, and as you watch him day by day you find him getting gradually more torpid and more indifferent. Then you see that his tongue has become greatly furred, often of a fawn colour, like the old-fashioned drab great coat brown and dirty. Along with that there is loss of appetite, and the man has occasionally severe fits of vomiting. He brings up mucus and partially digested food and other matter in considerable quantity. And then you further find on inquiry that he complaing, if he can be got to complain at all, that he has some sort of uneasiness about his tinroat; and when you look into his throat you see that it is red and congested, and that, perhaps, there is a good deal of mucus clinging about the pillars of fauces, covering the tonsils and the back of the pharynx. Then you find that the patient gets worse day by day. Each day as you visit him you find that he has got more torpid and more indifferent. Later he becomes unconscious altogether," twitchings of the muscles, and perhaps actual convulsions occur, and after ten days or so, as a rule, he dies. Such chronic cases usually go on to a fatal result.

But uræmia takes many other forms according to the part of the nervous system which, in the particular individual, has a selective affinity for the particular sort of poison which is present. There may be uræmic blindness, not connected with retinal changes. Things seem dark to the patient-perhaps he is actually blind as if the centrez for vision were temporarily disturbed by the action of the poison by which the uræmia is produced. Then the patient may become paralytic or paretic in some part or another, or he may suffer from uræmic dyspnœa in consequence of poisoning of the respiratory centre. Then there may be vomiting, partly of cerebral and partly of gastric origin, and there may be mental symptoms of such intensity that the patient may for a time be practically insane.

Now why do these thing s happen? Three theories have been suggested. Some people have maintained a mechanical theory, according to which there is dropsy of the brain, and want of blood in the vessels in consequence of the serous effusion, but there are only visy few cases, if, indeed, there are are truly any, which can be explained in this way. Then it has been referred to excess of urea. But it was found that urea introduced into the b'ood did not produce it, and that excess of urea might be found in the blood withoutany convulsions. Then Frerichs, of Berlin, invented the notion that the urea becoming broken up into carbonate of ammonia and water produced the condition, but the same argument applied to that also. There was no excess of carbonate of ammonia in the blood of uræmics, and carbonate of ammonia put into the blood did not produce convulsions like those of uræmia; and so that idea went to the wall. Then, lastly, it might be due to retained waste products, and in regard to this Sir Grainger S:ewart s ys, "I think it very probable indeed that waste products of the tissues-abnormal materials produced in the tisoues during the process of tissue change-are to be blamed for the occurrence of uræmic conditions." This brings us, then, to a consideration of the conditions which precipitate a uræmic attack. Except in the purely chronic cases, in which we may imagine the 